\title{
CONTEXTUAL TEACHING AND LEARNING (CTL) TERHADAP KEMAMPUAN PEMAHAMAN KONSEP MATEMATIKA SISWA KELAS VIII SMP
}

\author{
Rika Firma Yenni ${ }^{1}$, Malalina ${ }^{2}$ \\ ${ }^{1,2}$ Universitas Tamansiswa Palembang \\ ${ }^{1}$ rika_firma@unitaspalembang.ac.id
}

\begin{abstract}
The purpose of this study was to determine the effect of Contextual Teaching and Learning (CTL) learning on the ability to understand mathematical concepts of Grade VIII students of SMPIT Izzuddin Palembang. The population in this study were all students of class VIII SMPIT Izzuddin Palembang in the academic year 2018/2019. Samples taken in this study through the Random Sampling Technique. From the population, two classes were taken as the experimental class (VIII Damascus), amounting to 20 students and the control class (VIII Palestine), amounting to 20 students. The method used is the True Experiment Design namely the Posttest - Only Control Group Design category. Data collection is carried out by a test. The data obtained were analyzed using ttest. From the results of the study it can be concluded that there is a positive influence on the Contextual Teaching and Learning (CTL) approach to the ability to understand the mathematical concepts of Grade VIII students of SMPIT Izzuddin Palembang.
\end{abstract}

Key Words: Contextual Teaching and Learning (CTL), Ability to Understand Mathematical Concepts

\begin{abstract}
Abstrak: Tujuan dari penelitian ini adalah untuk mengetahui pengaruh pembelajaran Contextual Teaching and Learning (CTL) terhadap kemampuan pemahaman konsep matematika siswa kelas VIII SMPIT Izzuddin Palembang. Populasi dalam penelitian ini adalah seluruh siswa kelas VIII SMPIT Izzuddin Palembang tahun pelajaran 2018/2019. Sampel yang diambil dalam penelitian ini melalui Teknik Random Sampling. Dari populasi diambil dua kelas yang ada sebagai kelas eksperimen (VIII Damaskus) yang berjumlah 20 siswa dan kelas kontrol (VIII Palestina) yang berjumlah 20 siswa. Metode yang digunakan adalah True Eksperimen Design yaitu kategori Posttest - Only Control Group Design. Pengumpulan data yang dilakukan adalah dengan tes. Data yang diperoleh dianalisis dengan menggunakan uji-t. Dari hasil penelitian dapat disimpulkan bahwa ada pengaruh positif pendekatan Contextual Teaching and Learning (CTL) terhadap kemampuan pemahaman konsep matematika siswa kelas VIII SMPIT Izzuddin Palembang.
\end{abstract}

Kata Kunci: Contextual Teaching and Learning (CTL), Kemampuan Pemahaman Konsep Matematika

\section{PENDAHULUAN}

Pemahaman

(comprehension)

merupakan suatu kemampuan untuk mengartikan dan memahami suatu itu diketahui atau diingat dan memaknai arti dari bahan maupun materi yang dipelajari (Sagala, 2003). Sedangkan konsep (concept) merupakan buah 
pemikiran seseorang atau sekelompok orang yang dinyatakan dalam defenisi sehingga melahirkan produk pengetahuan meliputi prinsip, hukum, dan teori (Sagala, 2003). Konsep diperoleh dari fakta, peristiwa, pengalaman melalui generalisasi dan berfikir abstrak, serta penggunaan konsep untuk menjelaskan dan meramalkan. Sehingga pemahaman konsep adalah kompetensi yang ditunjukkan siswa dalam memahami konsep dan dalam melakukan prosedur (algoritma) secara luwes, akurat, efisien, dan tepat (Yustisia, 2008).

Sari (2015) menjelaskan pokok permasalahan yang dihadapi dalam pembelajaran matematika adalah kegiatan belajar mengajar di kelas masih didominasi oleh guru. Guru masih terbiasa pada kebiasaannya mengajar dengan menyajikan materi pembelajaran seperti memberikan contoh soal dan meminta siswa mengerjakan soal latihan yang terdapat dalam buku teks yang digunakan dalam mengajar dan kemudian membahasnya bersama siswa. Selain itu sebagian siswa sangat jarang mengajukan pertanyaan pada guru.

Dalam suatu proses pembelajaran membutuhkan metode yang tepat. Kesalahan menggunakan metode, dapat menghambat tercapainya tujuan Pendidikan yang diinginkan. Dampak lain adalah rendahnya kemampuan bernalar siswa dalam pembelajaran matematika. Hal ini disebabkan karena dalam proses pembelajaran siswa kurang dilibatkan dalam situasi optimal untuk belajar, pembelajaran cenderung berpusat pada guru. Selain itu siswa kurang dilatih untuk menganalisis permasalahan matematika. Jarang sekali siswa menyampaikan ide untuk menjawab pertanyaan bagaimana proses penyelesaian soal yang dilontarkan guru (Mudhofar, 2008).

Pendekatan yang akan digunakan adalah Contextual Teaching and Learning (CTL), yaitu suatu strategi pembelajaran yang menekankan kepada proses keterlibatan siswa secara penuh untuk dapat menemukan materi yang dipelajari dan menghubungkan dengan situasi kehidupan sehari-hari (Sanjaya, 2011). Dengan menggunakan pendekatan CTL diharapkan siswa untuk dapat berperan aktif dengan bimbingan guru, agar peningkatan kemampuan siswa dalam memahami konsep matematika khususnya materi bangun ruang menjadi lebih baik.

Pendekatan CTL merupakan konsep belajar yang membantu guru mengaitkan antara materi yang diajarkan dengan situasi dunia nyata siswa dan mendorong siswa membuat hubungan antara pengetahuan yang dimilikinya dengan penerapannya dalam kehidupan mereka sebagai anggota keluarga dan masyarakat. CTL dapat merangsang siswa belajar aktif, dapat menimbulkan motivasi siswa untuk belajar, berpikir kritis, melatih siswa untuk berkomunikasi, membantu siswa dalam mempertajam pelajaran dan melatih siswa percaya diri. Untuk itu penulis menggunakan pendekatan CTL sebagai suatu alternatif dalam mengembangkan proses pembelajaran, yang bertujuan untuk mengetahui pengaruh pendekatan CTL terhadap kemampuan pemahaman konsep 
matematika siswa kelas VIII di SMPIT Izzuddin Palembang.

\section{TINJAUAN TEORETIS}

Pemahaman konsep merupakan kemampuan menangkap pengertian seperti mampu mengungkapkan suatu materi yang disajikan ke dalam bentuk yang lebih dipahami, mampu memberikan interpretasi dan mampu mengaplikasikannya. Pemahaman konsep merupakan tingkat kemampuan yang mengharapkan siswa mampu memahami arti dari konsep, situasi, serta fakta yang diketahuinya. Adapun indikator yang menunjukkan pemahaman konsep yang digunakan dalam penelitian ini, yaitu: (1) menyatakan ulang sebuah konsep; (2) mengklasifikasikan objek menurut sifat-sifat tertentu (sesuai dengan konsepnya); (3) memberi contoh dan non-contoh dari konsep; (4) menyajikan konsep dalam berbagai bentuk representasi matematis; (5) mengembangkan syarat perlu atau syarat suatu konsep; (6) menggunakan, memanfaatkan, dan memilih prosedur atau operasi tertentu; dan (7) mengaplikasikan konsep atau algoritma pemecahan masalah (Kesumawati, 2010).

Contextual Teaching and Learning (CTL) merupakan konsep belajar yang dapat membantu guru dalam mengaitkan antara materi yang diajarkannya dengan situasi dunia nyata siswa dan mendorong antara pengetahuan yang dimilikinya dengan penerapannya dalam kehidupan mereka sebagai anggota keluarga dan masyarakat (Riyanto, 2009). Ada tujuh komponen dalam pendekatan CTL: (1) konstruktivisme (constructivisme); (2) bertanya (questioning); (3) menemukan (inquiry); (4) masyarakat belajar (learning community); (5) pemodelan (modelling); (6) refleksi (reflection); dan (7) penilaian sebenarnya (authentic assessment) (Riyanto, 2009).

Menurut Widdiharto (2004), kelebihan pendekatan CTL adalah: (1) siswa lebih termotivasi karena materi yang disajikan terkait dekat dengan kehidupan sehari-hari; (2) materi yang disajikan lebih lama membekas dipikiran siswa karena dilibatkan aktif dalam pembelajaran; dan (3) siswa berpikir alternatif dalam membuat pemodelan. Sedangkan kekurangannya adalah: (1) tidak semua materi bisa disajikan dengan kontekstual, atau mengalami kesulitan mengaitkan; dan (2) membutuhkan waktu yang agak lama.

Langkah-langkah pendekatan CTL (Aqib, 2013) adalah: (1) kembangkan pemikiran bahwa siswa akan belajar lebih bermakna dengan cara bekerja sendiri, dan mengkonstruksi sendiri pengetahuan dan keterampilan barunya; laksanakan sejauh mungkin kegiatan inkuiri untuk semua topik; (3) kembangkan sifat ingin tahu siswa dengan bertanya; (4) ciptakan masyarakat belajar; (5) hadirkan model sebagai contoh pembelajaran; (6) lakukan refleksi diakhir pertemuan; dan (7) lakukan penilaian yang sebenarnya dengan berbagai cara.

Dalam pembelajaran CTL siswa menemukan hubungan penuh makna antara ide-ide abstrak dengan 
penerapan praktis di dalam konteks dunia nyata. Kemudian Siswa menginternalisasikan konsep melalui penemuan, penguatan, dan terhubungan. Jadi dengan pembelajaran CTL siswa tidak hanya sekedar menghafal materi yang dipelajari, tetapi membelajarkan siswa dalam memahami materi pembelajaran secara mendalam dengan mengaitkan materi pembelajaran ke konteks kehidupan nyata sehari-hari siswa agar proses pembelajaran lebih bermakna dan menyenangkan sehingga dapat merangsang minat dan motivasi siswa.

Materi yang digunakan dalam penelitian ini adalah luas permukaan kubus dan balok serta volume kubus dan balok.

\section{METODOLOGI PENELITIAN}

Populasi dalam penelitian ini adalah seluruh siswa kelas VIII SMPIT Izzuddin Palembang tahun pelajaran 2018/2019 dengan jumlah 40 siswa.
Untuk menentukan sampel penulis menggunakan teknik random sampling, dimana kelas VIII. Damaskus sebagai kelas eksperimen dan kelas VIII. Palestina sebagai kelas kontrol. Metode penelitian yang digunakan adalah metode eksperimen (posttest only control group design) dimana kelas eksperimen menggunakan pendekatan CTL, sedangkan kelas kontrol dengan pembelajaran konvensional.

Pelaksanaan penelitian dilakukan dengan 3 tahap yaitu: (1) tahap persiapan; (2) tahap pelaksanaan; serta (3) tahap evaluasi dan pengumpulan data. Teknik pengumpulan data menggunakan metode tes untuk mengukur kemampuan pemahaman konsep matematika pada tes akhir (posttest). Tes yang digunakan adalah tes bentuk uraian. Soal yang dibuat disesuaikan dengan 5 indikator kemampuan pemahaman konsep.

Tabel 1

Pedoman Penskoran Kemampuan Pemahaman Konsep

\begin{tabular}{|c|c|c|c|}
\hline No. & Indikator & Respon Siswa terhadap Soal & Skor \\
\hline \multirow[t]{4}{*}{1} & \multirow{4}{*}{$\begin{array}{l}\text { Menyatakan ulang } \\
\text { sebuah konsep }\end{array}$} & Tidak menjawab sama sekali & 0 \\
\hline & & Menjawab tetapi salah & 1 \\
\hline & & Menjawab tetapi belum lengkap & 2 \\
\hline & & Menjawab dengan lengkap dan benar & 3 \\
\hline \multirow[t]{4}{*}{2} & \multirow{4}{*}{$\begin{array}{l}\text { Menyajikan konsep } \\
\text { dalam berbagai } \\
\text { bentuk representasi } \\
\text { matematis }\end{array}$} & Tidak menjawab sama sekali & 0 \\
\hline & & Menyajikan konsep tetapi salah & 1 \\
\hline & & Menyajikan konsep tetapi belum lengkap & 2 \\
\hline & & $\begin{array}{l}\text { Menyajikan konsep dengan lengkap dan } \\
\text { benar }\end{array}$ & 3 \\
\hline \multirow[t]{4}{*}{3} & \multirow{4}{*}{$\begin{array}{l}\text { Mengembangkan } \\
\text { syarat perlu atau } \\
\text { syarat cukup suatu } \\
\text { konsep }\end{array}$} & Tidak menjawab sama sekali & 0 \\
\hline & & $\begin{array}{l}\text { Syarat yang diajukan dalam suatu konsep } \\
\text { tidak tepat }\end{array}$ & 1 \\
\hline & & $\begin{array}{l}\text { Syarat yang diajukan dalam suatu konsep } \\
\text { kurang lengkap }\end{array}$ & 2 \\
\hline & & $\begin{array}{l}\text { Syarat yang diajukan dalam suatu konsep } \\
\text { lengkap dan benar }\end{array}$ & 3 \\
\hline
\end{tabular}




\begin{tabular}{|c|c|c|c|}
\hline \multirow[t]{4}{*}{4} & \multirow{4}{*}{$\begin{array}{l}\text { Menggunakan, } \\
\text { memanfaatkan, dan } \\
\text { memilih prosedur } \\
\text { atau operasi tertentu }\end{array}$} & Tidak menjawab sama sekali & 0 \\
\hline & & $\begin{array}{l}\text { Menjawab tetapi prosedur atau operasinya } \\
\text { masih salah }\end{array}$ & 1 \\
\hline & & $\begin{array}{l}\text { Menjawab tetapi prosedur atau operasinya } \\
\text { kurang lengkap }\end{array}$ & 2 \\
\hline & & $\begin{array}{l}\text { Menjawab dengan prosedur atau operasi } \\
\text { dengan lengkap dan benar }\end{array}$ & 3 \\
\hline \multirow[t]{4}{*}{5} & \multirow{4}{*}{$\begin{array}{l}\text { Mengaplikasikan } \\
\text { konsep atau } \\
\text { algoritma } \\
\text { pemecahan masalah }\end{array}$} & Tidak menjawab sama sekali & 0 \\
\hline & & $\begin{array}{l}\text { Menjawab tetapi mengaplikasikan konsep } \\
\text { kurang tepat }\end{array}$ & 1 \\
\hline & & $\begin{array}{l}\text { Menjawab tetapi mengaplikasikan konsep } \\
\text { kurang lengkap }\end{array}$ & 2 \\
\hline & & $\begin{array}{l}\text { Menjawab dengan aplikasi konsep yang } \\
\text { lengkap dan benar }\end{array}$ & \\
\hline
\end{tabular}

Sumber: Modifikasi Hariyanto (2014)

Uji coba instrumen dilakukan di kelas non-sampel dengan 20 siswa. Teknik uji coba instrumennya adalah:

(1) Validitas Tes, dihitung dengan rumus Korelasi Product Moment

Tabel 2

Hasil validasi

\begin{tabular}{cccc}
\hline Soal & r-soal & r-tabel & Status \\
\hline 1 & 0,679 & 0,444 & Valid \\
\hline 2 & 0,595 & 0,444 & Valid \\
\hline 3 & 0,570 & 0,444 & Valid \\
\hline 4 & 0,740 & 0,444 & Valid \\
\hline 5 & 0,678 & 0,444 & Valid \\
\hline 6 & 0,678 & 0,444 & Valid \\
\hline 7 & 0,700 & 0,444 & Valid \\
\hline
\end{tabular}

(2) Uji Reliabilitas, menggunakan rumus Alpha. Semua soal reliabel.

Tabel 3

Hasil Reliabilitas Soal

\begin{tabular}{|c|c|c|c|c|}
\hline No & $\begin{array}{l}\text { Varian } \\
\text { Skor } \\
\text { Butir }\end{array}$ & $\begin{array}{c}\text { Varian } \\
\text { Skor } \\
\text { Total } \\
\end{array}$ & $\mathbf{r}_{\text {tabel }}$ & $\mathbf{r}_{\mathrm{xy}}$ \\
\hline 1 & 5,027 & \multirow{7}{*}{232,24} & \multirow{7}{*}{0,444} & \multirow{7}{*}{0,817} \\
\hline 2 & 7,76 & & & \\
\hline 3 & 7,64 & & & \\
\hline 4 & 8,29 & & & \\
\hline 5 & 16,24 & & & \\
\hline 6 & 10,527 & & & \\
\hline 7 & 14,19 & & & \\
\hline
\end{tabular}

(3) Tingkat Kesukaran Soal, semua soal termasuk kriteria sedang.

Tabel 4 Tingkat Kesukaran Butir Soal

\begin{tabular}{ccc}
\hline No & $\begin{array}{c}\text { Tingkat } \\
\text { Kesukaran }\end{array}$ & Kriteria \\
\hline 1 & 0,51 & Sedang \\
\hline 2 & 0,41 & Sedang \\
\hline 3 & 0,47 & Sedang \\
\hline 4 & 0,41 & Sedang \\
\hline 5 & 0,37 & Sedang \\
\hline 6 & 0,39 & Sedang \\
\hline 7 & 0,41 & Sedang \\
\hline
\end{tabular}

(4) Daya Pembeda, semua daya pembeda soal termasuk kriteria cukup dan jelek.

Tabel 5

Daya Pembeda Butir Soal

\begin{tabular}{|c|c|c|}
\hline No & Daya Pembeda & Kriteria \\
\hline 1 & 0,20 & Cukup \\
\hline 2 & 0,15 & Jelek \\
\hline 3 & 0,22 & Cukup \\
\hline 4 & 0,25 & Cukup \\
\hline 5 & 0,37 & Cukup \\
\hline 6 & 0,18 & Jelek \\
\hline 7 & 0,36 & Cukup \\
\hline
\end{tabular}

menggunakan uji-t pihak kanan dengan hipotesis, ada pengaruh pembelajaran CTL terhadap kemampuan pemahaman 
konsep matematika siswa kelas VIII SMPIT Izzuddin Palembang. Sebelum melakukan uji hipotesis dilakukan uji normalitas (Teknik Kolmogrov Smirnov) dan uji homogenitas (Uji Bartlett).

\section{HASIL DAN PEMBAHASAN}

Penelitian ini dilaksanakan mulai tanggal 25 April 2018 sampai 25 Mei 2018 dengan 3 tahap yaitu perencanaan, pelaksanaan, dan evaluasi. Pada tahap perencanaan penulis melakukan observasi ke sekolah dan mengadakan wawancara dengan guru bidang studi. Pembelajaran dilakukan dalam 3 kali pertemuan dan 1 kali pertemuan untuk tes akhir di kelas eksperimen dan kontrol.

Pelaksaan penelitian dikelas eksperimen menggunakan pendekatan CTL. Pembelajaran dibagi menjadi 3 tahap yaitu:

(1) Kegiatan pendahuluan, dengan memberikan apersepsi dan motivasi

(2) Kegiatan inti, dengan menerapkan 6 komponen dalam pendekatan CTL yaitu: (a) konstruktivisme (mengkondisikan siswa pada posisi siap belajar; (b) masyarakat belajar (mengelompokkan siswa menjadi 4 kelompok diskusi; (c) pemodelan (membagikan kotak berbentuk kubus dan balok beserta gunting, siswa membuka kotak tersebut menjadi jaring-jaring kubus dan balok, pada pertemuan ketiga membagikan kotak karton berbentuk kubus dan balok yang dipenuhi dengan kubus dan balok kecil dengan ukuran yang sama); (d) menemukan (menemukan rumus menghitung luas permukaan kubus dan balok dari jaringjaringnya serta menenukan rumus menghitung volume kubus dan balok); (e) bertanya (membimbing siswa yang mengalami kesulitan dalam mengerjakan LKS); (f) penilaian sebenarnya (anggota kelompok memaparkan hasil temuan dan hasil diskusinya)

(3) Kegitan penutup, dengan menerapkan 2 komponen pada pendekatan CTL yaitu; (a) penilaian sebenarnya (memberikan tes diakhir pertemuan); (b) refleksi (menyimpulkan materi yang telah dipelajari)

Materi yang disampaikan adalah menemukan luas permukaan kubus dan balok serta volume kubus dan balok.

Kemampuan pemahaman konsep matematika siswa dilihat dari evaluasi belajar melalui tes yang dilaksanakan diakhir pertemuan setelah menerapkan pembelajaran dengan pendekatan CTL. Kemudian dilakukan analisis data untuk menguji hipotesis penelitian (ujit).

Tabel 6

Hasil Tes Akhir Kelas Eksperimen

\begin{tabular}{cc}
\hline Interval & Frekwensi \\
\hline $71-76$ & 8 \\
\hline $77-82$ & 0 \\
\hline $83-88$ & 3 \\
\hline $89-94$ & 4 \\
\hline $95-100$ & 5 \\
\hline Jumlah & 20 \\
\hline Dari data diperoleh rata-rata tes \\
kemampuan pemahaman konsep \\
matematika & siswa pada kelas
\end{tabular}


eksperimen 84,90 dengan simpangan bakunya 10,28 .

\section{Tabel 7}

Hasil Tes Akhir Kelas Kontrol

\begin{tabular}{cc}
\hline Interval & Frekwensi \\
\hline $25-35$ & 3 \\
\hline $36-44$ & 3 \\
\hline $45-53$ & 4 \\
\hline $54-62$ & 4 \\
\hline $63-71$ & 6 \\
\hline Jumlah & 20 \\
\hline
\end{tabular}

Dari data diperoleh rata-rata tes kemampuan pemahaman konsep matematika siswa pada kelas kontrol 52,15 dengan simpangan bakunya 13,14 .

Untuk uji normalitas kedua kelas sampel menggunakan statistik kemiringan dan kemencengan kurva (km). Nilai km kelas eksperimen 1,109, terletak antara $-1<\mathrm{km}<+1$ sehingga dapat disimpulkan bahwa kelas eksperimen berdistribusi normal. Nilai $\mathrm{km}$ kelas kontrol -0,958, terletak antara $-1<\mathrm{km}<+1$ sehingga dapat disimpulkan bahwa kelas kontrol berdistribusi normal.

Uji homogenitas digunakan untuk menguji kesamaan variabel dalam penelitian menggunakan uji Bartlett. Didapatkan nilai variansi gabungan kedua kelas sampel adalah 139,295 dan harga chi-kuadrat hitung adalah 1,136. Dengan $\alpha=0,05$ dan harga chi-kuadrat tabel adalah 3,840. Ternyata chi-kuadrat tabel lebih besar dari chi-kuadrat hitung $(3,840>1,136)$ maka variansi dikatakan homogen.

Dari hasil analisis diketahui kedua sampel berdistribusi normal dan mempunyai variansi yang homogen, sehingga dapat dilakukan pengujian hipotesis dengan uji-t. Diperoleh nilai t hitung sebesar 8,770. Untuk nilai t tabel menggunakan taraf signifikan $\alpha=$ 0,05 dan $\mathrm{dk}=\mathrm{n}_{1}+\mathrm{n}_{2}-2=20+20-2$ $=38$, sehingga diperoleh nilai $\mathrm{t}$ tabel sebesar 1,684.

Kriteria pengujian hipotesis terima $\mathrm{H}_{0}$ jika $\mathrm{t}$ hitung $<\mathrm{t}$ tabel dan terima $\mathrm{H}_{1}$ jika sebaliknya. Setelah dilakukan perhitungan maka diperoleh: $\mathrm{t}$ hitung > $\mathrm{t}$ tabel $(8,770>1,684)$. Sehingga $\mathrm{H}_{0}$ ditolak dan terima $\mathrm{H}_{1}$. Jadi dapat disimpulkan ada pengaruh pendekatan CTL terhadap kemampuan pemahaman konsep matematika siswa kelas VIII SMPIT Izzuddin Palembang. Kemampuan pemahaman konsep matematika siswa yang menggunakan pendekatan CTL lebih baik daripada yang menggunakan pembelajaran konvensional.

Sesuai dengan pendapat Hosnan (2014), terdapat beberapa kelebihan CTL seperti: (1) pembelajaran menjadi lebih bermakna dan riil; (2) pembelajaran lebih produktif dan mampu menumbuhkan penguatan konsep kepada siswa; (3) menganut aliran konstruktivisme, dimana seorang siswa dituntut untuk menemukan pengetahuannya sendiri. Melalui landasan filosopis konstruktivisme siswa diharapkan belajar melalui "mengalami” bukan "menghapal".

\section{SIMPULAN DAN SARAN}

Berdasarkan hasil analisis dan pembahasan, dapat disimpulkan bahwa ada pengaruh pembelajaran dengan pendekatan CTL terhadap kemampuan pemahaman konsep matematika siswa kelas VIII SMPIT Izzuddin Palembang. Pembelajaran dengan pendekatan CTL 
dapat membuat siswa berperan aktif dalam proses belajar mengajar, meningkatkan kemampuan siswa dalam memahami konsep matematika. Sekiranya penggunaan pendekatan CTL dapat sebagai bahan masukan dalam pembelajaran matematika yang lebih efektif serta dapat menciptakan suatu kegiatan belajar yang menarik bagi siswa.

\section{DAFTAR PUSTAKA}

Aqib, Zainal. 2013. Model-model, Media, dan Strategi Pembelajaran Kontekstual (Inovatif). Bandung : CV Yrama Widya.

Hariyanto. 2014. Asessmen Pendidikan. Bandung : PT Remaja Rosdakarya.

Hosnan. 2014. Pendekatan Saintifik dan Kontekstual dalam Pembelajaran Abad 21. Bogor : Ghalia Indonesia.

Kesumawati, Nila. 2010. Mengembangkan Penalaran dalam Matematika. Makalah disampaikan dalam Prosiding Seminar Nasional Matematika dan Pendidikan Matematika pada Tanggal 27 November 2007 di Yogyakarta.

Mudhofar, Hafid. 2008. Model Pembelajaran Berbasis Contextual Teaching and Learning untuk Peningkatan Pemahaman Konsep. (Online). (http://etd.eprints.ums.ac.id/2111/1 /A410040191.pdf, diakses pada 27 Desember 2017).

Riyanto, Yatim. 2009. Paradigma Baru Pembelajaran: sebagai Referensi bagi Guru/Pendidik dalam Implementasi Pembelajaran yang Efektif dan Berkualitas. Jakarta : Kencana Prenada Media Group.

Sagala, Syaiful. 2003. Konsep dan Makna Pembelajaran untuk Membantu Memecahkan
Problematika Belajar Mengajar. Bandung: Alfabeta.

Sanjaya, Wina. 2011. Strategi Pembelajaran Berorientasi Standar Proses Pendidikan. Jakarta : Kencana Prenada Media Group.

Sari, Nurahmi Dwi. 2015. Pengaruh Model Pembelajaran Contextual Teaching and Learning (CTL) terhadap Kemampuan Pemahaman Konsep Matematika Siswa di SMP Negeri 30 Palembang. Skripsi : Tidak diterbitkan.

Widdiharto, Rachmadi. 2004. Modelmodel Pembelajaran Matematika SMP. Yogyakarta : Depdiknas Direktorat Jenderal Pendidikan Dasar dan Menengah Pusat Pengembangan Penalaran Guru (PPPG) Matematika.

Yustisia, Tim Pustaka. 2008. Panduan Lengkap KTSP (Kurikulum Tingkat Satuan Pendidikan). Yogyakarta : Pustaka Yustisia. 